ER

33,4

334

\section{Varieties of capitalism, governance, and high-tech export performance}

\section{A fuzzy-set analysis of the new EU member states}

\author{
Matthew M.C. Allen \\ Manchester Business School, The University of Manchester, \\ Manchester, UK, and \\ Maria L. Aldred \\ Manchester Metropolitan University Business School, Manchester, UK
}

\begin{abstract}
Purpose - This paper aims to assess the extent to which convergence in institutional regimes is likely to occur, by examining all ten new EU member states in Central and Eastern Europe in terms of their development of comparative advantages in high-tech export markets either by drawing on foreign investors in the form of multinational companies or by making use of domestic institutional resources.

Design/methodology/approach - The article uses fuzzy sets and qualitative comparative analysis to examine both necessary and sufficient causes of success in high-tech export markets. By doing so, it can address the important issue of institutional complementarity.

Findings - While it finds that countries that have stronger records in such markets share common features, there are also important differences between them - not least in the areas of employee relations. This, together with other evidence presented in the paper, suggests that convergence around a specific institutional model is unlikely to happen.

Originality/value - Analysing, unlike many previous studies, all ten new EU member states in Central and Eastern Europe enables conclusions to be drawn that apply to the whole region. The novel method used in this article means that the extent of any complementarity between different institutions can be addressed, and ensures that issues relating to convergence/divergence are explored. The article, therefore, contributes to a number of important debates on the convergence among types of capitalism, the dependency of the new EU member states on foreign investors, and the institutional foundations for success in high-tech export markets.
\end{abstract}

Keywords Organizations, Central and Eastern Europe, Convergence, Employee relations, Fuzzy sets, High-technology exports

Paper type Research paper

\section{Introduction}

The new member states of the European Union (EU) in Central and Eastern Europe (CEE) provide a strong basis on which to assess trends in corporate governance regimes and employment relations. Indeed, they offer prime cases to study the extent to which these systems are likely to converge - if they do not follow more path-dependent trajectories (Czaban and Henderson, 2003; Djankov et al., 2003; Hall and Soskice, 2001a;

Whitley, 1999) - around a common CEE model or around those associated with neo-liberal forms of capitalism. The reasons for this are threefold. First, the new 
member states are highly dependent on foreign direct investment (FDI) (Bohle and Greskovits, 2006; Lane and Myant, 2007; Nölke and Vliegenthart, 2009). Second, the competition between the new member states for such investment is likely to lead to pressures to create corporate-governance and employment regulations that are most attractive to foreign companies and, hence, that are likely to impose fewer constraints on business and institutional entrepreneurs than might otherwise be the case (Hansmann and Kraakman, 2000; Lane, 2007; McCahery et al., 2004; Walgenbach and Meyer, 2008). Finally, the collapse of communism in the region represented an opportunity to introduce changes during a period when limitations to change may have been weakened (Vaughan-Whitehead, 2003).

The issues of potential institutional convergence within the region have been addressed from a variety of perspectives. For instance, political-economy scholars have attempted to trace the extent to which open capital markets have led to convergence around neo-liberal models of corporate governance and employment regulations in the region (Knell and Srholec, 2007; Lane, 2007; Nölke and Vliegenthart, 2009). Others, drawing, inter alia, on aspects of the literature on global commodity chains, have analysed these issues from a business perspective (see, for instance, Czaban and Henderson, 2003; Henderson, 1998). Despite these differing perspectives, there are a number of commonalities among previous studies. First, several important studies have either tended to treat the new member states (or a sub-set of them) as a relatively homogeneous group (Crowley, 2004; King and Sznajder, 2006; Lane, 2005; Mykhnenko, 2007; Nölke and Vliegenthart, 2009; see Allen and Aldred, 2009; Bohle and Greskovits, $2007 \mathrm{a}, \mathrm{b}$ ) or focused on a very small number of countries in the region (Buchen, 2007; Czaban and Henderson, 2003; Feldmann, 2004, 2006). Second, the extent to which the new member states are dependent on firms in other countries has often been assessed, according to the OECD's (2005, p. 172) classification of industries by technology intensity, in terms of medium-high-, medium-low- and low-technology sectors (Bohle and Greskovits, 2006; Czaban and Henderson, 2003; Nölke and Vliegenthart, 2009), but not specifically high-technology industries. Finally, despite the differing emphases in the focus of previous studies, many have used the "Varieties of capitalism" paradigm as an analytical starting point (see, for instance, Allen and Aldred, 2009; Bohle and Greskovits, 2007b; Czaban and Henderson, 2003; Knell and Srholec, 2007; Lane and Myant, 2007; Nölke and Vliegenthart, 2009).

From this common starting position, a theme that is emerging in the literature is the degree to which countries in CEE represent a different variety of capitalism, in general, and, more specifically, the extent to which they are dependent on foreign investors to increase their innovative capabilites (Bohle and Greskovits, 2007b; Dörrenbächer, 2007; Nölke and Vliegenthart, 2009). Much of this literature paints a relatively pessimistic picture of the ability of countries in the region to break out of their dependency status towards a path of economic development based on more radical forms of innovation. For instance, Bohle et al. (2007, p. 83) have argued that:

A major feature of FDI in ECE [Eastern Central Europe] is that it is less market seeking than efficiency seeking. A new cross-European division of labour has emerged, in which peripheral eastern European locations compete with southern European countries for core types of economic activities, and increasingly with western European countries.

Two corollaries of such contentions are that, first, FDI into the region is not strategic asset seeking, and, second, firms in the region do not have the competencies to ward off

\section{Varieties of capitalism}

335 
ER

33,4

336 competition from companies in other countries. This latter point means that they cannot differentiate themselves greatly from others in the region. It also means that their sole competitive advantage is low cost.

In a similar vein, Nölke and Vliegenthart (2009, p. 678) have argued that "Dependent market economies are expected to be used as assembly platforms based on innovations that are made at TNC [transnational corporation] headquarters and transferred within TNC hierarchies." In this perspective, subsidiaries are portrayed as relatively passive recipients of knowledge that is generated elsewhere. However, it should be noted that the transfer of innovations may not be as straightforward as it might first appear: "tacit knowledge" (Polanyi, 1966) may create friction, and the subsidiary may lack the requisite "absorptive capacity" (Cohen and Levinthal, 1990) to commercialize that innovation successfully. Nölke and Vliegenthart's (2009) depiction of subsidiaries implies that knowledge transfer primarily takes places from the headquarters to the subsidiary; by doing so, it downplays the importance of the subsidiary's embeddedness within the host-country's economy. This overlooks the potential benefits that may spillover from the foreign-owned subsidiary to host-country firms. While links between these two sets of organizations are often lacking (Dörrenbächer, 2007), they cannot be discounted at the outset. What is common to both Bohle et al.'s (2007 and Nölke and Vliegenthart's (2009) portrayal of foreign-owned subsidiaries in CEE is that those organizations lack the ability to move into higher value-added activities.

This paper examines such issues by assessing the links between, in the one hand, inward FDI and institutions, and, on the other, high-tech exports. If it can be shown that inward FDI is associated with stronger levels of high-tech exports, this would suggest that firms in the region are able to upgrade their capabilities so that they are valuable, rare, difficult to imitate and non-substitutable (Barney, 1991). Such capabilities will increase the autonomy of foreign-owned subsidiaries vis-à-vis headquarters in their attempts to gain an enlarged role (Dörrenbächer, 2007). Thus, a very different picture of the development of CEE economies may emerge.

This has implications for the degree to which institutional frameworks in the region are likely to converge around a particular pattern. For instance, if it can be shown that low levels of employee participation in company decision making are either necessary and/or sufficient for increased levels of high-tech exports, then this would indicate a potential policy for others to follow. If, on the other hand, there are various means by which countries can gain comparative advantages in high-tech markets, then continued divergence can be expected.

\subsection{Research aims, and contribution}

This paper examines the issue of convergence in corporate governance regimes and employment relations in CEE in a number of ways. First, the analysis covers all ten member states from CEE that joined the EU in either 2004 or 2007. Second, to assess the extent to which the new EU member states in CEE have become "dependent market economies" (Nölke and Vliegenthart, 2009), this study focuses specifically on the links between FDI and institutions, on the one hand, and high-tech exports, on the other. Third, the research is based on fuzzy-set qualitative comparative analysis (Ragin, 2000, 2006,2008 ) that is increasingly being used in related studies to identify the complex institutional configurations of both sufficient and necessary causes of various 
outcomes (Boyer, 2004; Jackson, 2005; Pajunen, 2008; Schneider et al., 2009). This, in turn, can help to shed light on issues of complementarity (Crouch, 2005).

Including all ten new $\mathrm{EU}$ member states in $\mathrm{CEE}$ in the analysis has the benefit of shedding greater light on the potentially important differences between them. Greater awareness of this diversity will help to shed light on the potential sectoral unevenness and experimental nature of systemic change within these countries. The focus on high-technology exports has a number of benefits. First, as noted above, previous studies have often included sectors that have lower levels of technology intensity (Bohle and Greskovits, 2006, 2007b; Buchen, 2007; Mykhnenko, 2007). This may lead analysts to relatively pessimistic conclusions about the economic prospects of the new member states: if those countries are dependent on outside investors to create jobs that are, on the whole, related to semi- or low-skilled labour, then, once the cost advantages of the region are reduced, that inflow of foreign capital will dry up (Bohle and Greskovits, 2007a; Nölke and Vliegenthart, 2009).

The focus on high-technology sectors in this paper, by contrast, will help to reveal greater levels of skills and knowledge within firms in the region, as the successful transfer of the production of high-technology products to CEE will require sufficient levels of "absorptive capacity" (Cohen and Levinthal, 1990) among companies there. If firms lack this capacity, firms may be unable to export their products, despite having access to lower-cost employees. This, in turn, may reveal the willingness of foreign firms to increase the organizational capabilities of their subsidiaries in the region, and, hence, point to a more optimistic assessment of the region's future economic prospects. The ways in which countries in the region are used by MNCs as an export base for either low-cost manufacturing or increasingly sophisticated products that require some transfer of capabilities from foreign-owned firms have important implications for both internal diversity and institutional change, a significant emerging theme within the broader literature (Aoki and Jackson, 2008; Deeg, 2009, 2010; Lane and Wood, 2009; Morgan, 2009).

An additional benefit of focusing on high-technology industries is that they have been closely associated with radical innovation (Allen et al., 2006; Casper, 2009; Casper and Whitley, 2004; Hall and Soskice, 2001a). It is contended that radical innovation is favoured by institutional configurations associated with liberal market economies (LMEs), such as the USA and the UK (Casper and Whitley, 2004; Hall and Soskice, 2001a). Therefore, it can be expected that it will be those countries in CEE whose institutional frameworks, especially in the areas of corporate governance and employment regulations, most closely resemble LME-type frameworks that will be the ones - if foreign investors are willing to transfer or establish relevant organizational capabilities to the region - most closely associated with greater levels of high-tech exports. This, in turn, may indicate that the pressures to converge towards more Anglo-American models of corporate governance and employment regulations are strong. If, on the other hand, countries with institutional settings that do not closely conform to the LME ideal type, then this may reveal less pressure for convergence.

The use of fuzzy sets has several advantages. First, the technique enables the identification of any potential patterns in both necessary and sufficient causal conditions of success in high-tech exports. The identification of any such patterns will highlight the potential role of foreign investors and any typical patterns that are associated with high-tech exports. This, in turn, will help to establish the extent to
Varieties of
capitalism

337 
ER

33,4

338 which corporate governance regimes and employment regulations are likely to converge across the region to a common - potentially, LME-type - model. In addition, if a common institutional pattern is found for those countries that have greater levels of high-tech exports, this could point to policies that others could seek to emulate. This would raise issues of how countries can up-grade the capabilities of firms operating within them. Alternatively, if no common institutional configuration is found that can explain export success in high-tech products, then this will illustrate that diversity within the region will persist, as there will be more than one way to achieve success in this important area. Second, fuzzy sets are particularly appropriate for research designs that are limited to a relatively small number of observations, which is often the case with cross-country analyses (Jackson, 2005). Finally, fuzzy sets facilitate a more nuanced examination of "causal complexity" to put it one way (Ragin, 2008) or "institutional complementarities" as others have put it (Hall and Soskice, 2001a; Whitley, 2007). This, hence, facilitates the assessment of combinations of factors, which is important as the issue of complementarity within the institutionalist literature has been scrutinized extensively (see, for example, Crouch, 2005; Crouch et al., 2005; Morgan, 2005).

The following sections set out the main arguments of the $\mathrm{VoC}$ literature in the areas of corporate governance, and employment regulations. In addition, more general business regulations and educational levels are discussed, as these can be expected to have an influence on exports of high-technology products. Those sections also provide information on these issues for the new member states in CEE. The data and variable calibrations are then discussed. Before the data are assessed, the analytical method used and the data are set out. Finally, conclusions are drawn and suggestions for future research made.

\section{Corporate governance}

The issue of corporate governance is one that is central to the $\mathrm{VoC}$ framework (Hall and Soskice, 2001a) and that has been highlighted as an important distinguishing feature of capitalism in CEE (King, 2007; Nölke and Vliegenthart, 2009). However, the term is treated slightly different within these different perspectives. This section sets out those differences, and puts forward ways in which they might be operationalized.

Within the VoC approach, one of the key issues in corporate governance is formal regulations, and the ways in which these influence the decision-making process within firms at the company level. In terms of regulations, a distinction is drawn between those countries, such as Germany, that formally require large companies to have employees represented on the supervisory board and other countries, such as the UK and the USA, that have no such requirements. Although employee representatives on supervisory boards of large German companies can be out-voted by those who represent shareholder interests, their position means that they can influence the strategic decisions of companies to a greater extent than, say, workforce representatives in the UK. In short, it is contended that the differences in corporate-governance regimes between "co-ordinated market economies" (CMEs), such as Germany and Sweden, and LMEs, such as the UK and the USA, shape the decisions that firms take, and, as a result, influence the organizational capabilities that companies are able to generate and maintain. 
It is not just, however, the formal regulations that the $\mathrm{VoC}$ paradigm subsumes under the corporate governance rubric. The $\mathrm{VoC}$ paradigm also deals with the issue of corporate finance, and the ways in which this, too, shapes firms' organizational capabilities and, hence, competitive strategies (Casper and Matraves, 2003; Hall and Soskice, 2001a). In CMEs, firms rely, in general, relatively heavily on bank-based financing. In LMEs, by contrast, capital markets play a greater role in financing companies. This has important consequences for the pressures on firms, and, hence, the decisions that senior managers within them are likely to take. In the former group of countries, banks are said to provide more "patient capital", and they are often represented on the supervisory boards of the firms that they have lent money to. As a result, banks have a more detailed understanding of the investment and strategic decisions of companies. This may enable companies to undertake investments whose pay off is over the long rather than the short term. It will also mean, however, that banks will be reluctant to see companies radically alter their strategies into product markets that are new to the companies. Consequently, firms will be encouraged to pursue strategies based on the incremental up-grading of their products. By contrast, firms in LMEs will be under pressure to ensure they meet the short-term profitability targets of institutional investors (Hall and Soskice, 2001b; see Gospel and Pendleton, 2004). As a result, firms will be encouraged to move into markets that offer them the greatest financial returns.

Within the VoC paradigm, in a broad sense, authority sharing between firms can also be seen as an influence on the key decisions taken by firms, and, hence, as a part of corporate governance (Hall and Soskice, 2001a; Whitley, 1999, 2007). Within CMEs, the institutional framework (including typical financing patterns) within which firms operate can support strategies that are based on mutual commitment. For instance, a supplier may be able to establish relational forms of contracting with a customer, as the likelihood of that customer imposing price cuts unilaterally or arbitrarily changing the terms of a contract are less than they are in LMEs, where firms may pursue such activities in order to restore or increase their short-term profits. These mutual commitments are, however, likely to constrain the degree to which firms can radically alter their strategies in CME-type economies (Whitley, 2007, p. 180). By contrast, forging such relational contracting in LMEs will be more difficult. While this may make the creation of long-term commitments between two firms in CMEs more difficult, it also means that the extent to which strategic-decision makers are constrained by other firms will, typically, be less in LMEs than it is in CMEs.

It is this latter conceptualization of corporate governance that underpins an important contribution to the literature on varieties of capitalism within CEE (Nölke and Vliegenthart, 2009; but see also Bohle and Greskovits, 2006; King, 2007). As a result of the large amount of foreign investment in $\mathrm{CEE}$ and as result of formerly state-owned enterprises being privatized and then taken over by overseas companies, it is argued that there have been important changes to the corporate-governance systems of enterprises in the region (see, for instance, Czaban and Henderson, 2003). In particular, Nölke and Vliegenthart (2009, pp. 682-3) contend that:

[...] major corporate decisions are not negotiated between managers and shareholders, but rather between managers of the [East Central Europe] subsidiary and Western headquarters. [...] As a result, corporate managers of [East Central Europe] subsidiaries are responsible to internal supervisors in other countries.

\section{Varieties of capitalism}

339 
ER

33,4

340

It is, therefore, the greater prevalence of foreign ownership that distinguishes firms in CEE from those in LMEs and CMEs (King, 2007; Lane, 2007). In addition, it supports the relatively pessimistic outlook for the region, as firms in CEE are not in charge of their own destinies. Indeed, the influence of those outside the countries of CEE does not stop there: the corporate-governance codes of the region have been strongly shaped by transnational entities (Nölke and Vliegenthart, 2009). On this reading of investments in the region, therefore, those corporate governance regimes that least constrain foreign investors will be the ones most attractive to them.

Indeed, foreign organization may shape the capabilities of firms in CEE in other potentially less direct-ways. For instance, banks in CEE are often foreign owned (Bohle and Greskovits, 2006) and overseas investors own a large proportion of equities that are listed on the region's stock markets (Allen and Aldred, 2009). If foreign investors wish to have a more direct influence over CEE companies, they will own outright their overseas subsidiaries. This, in turn, will mean that they are not listed on local stock markets and, hence, will not have to adhere to the necessary host-country regulations. Consequently, host-country stock markets will be of little relevance to them (Lane, 2007; Myant, 2007; Mykhnenko, 2007). Additionally, wholly owned subsidiaries may be less likely to be reliant on banks in the region for funding.

If FDI is, indeed, the preferred route for foreign companies to co-ordinate and control their subsidiaries in CEE, then those countries that attract the most FDI may not be the ones to exhibit the strongest export records for high-tech goods, if countries in the region are being used to perform relatively low-skilled activities. If, on the other hand, domestically owned firms are able to export successfully high-tech products, then, because they are likely to rely more on domestic sources of funding either from banks or stock markets, an association between these two factors and success in high-tech markets can be expected. If such an association is found, this will reveal that convergence pressures may be less than is sometimes contended (see, for instance, Shields, 2007). Importantly for this paper, then, the degree to which high levels of FDI are associated with greater exports of high-tech goods will help to assess whether or not MNCs use countries in CEE "as assembly platforms for semistandardized goods" (Nölke and Vliegenthart, 2009, p. 687), which implies lower high-tech exports and lower organizational capabilities.

\section{Employment regulations}

Another key element of the $\mathrm{VoC}$ framework is the employment system which covers various forms of employment regulations, such as employment protection, wage bargaining and workplace representation. Although this aspect of that framework is treated in a separate section here, the complementarities and links between employment regulations and corporate governance regimes should not be forgotten (Hall and Soskice, 2001a; Höpner, 2005).

At the establishment level, employment regulations in CMEs provide employee representatives with relatively powerful means to convey the views of workers to managers. Indeed, in some areas, employee representatives must give their consent to proposed changes. In CMEs, sectoral bargaining plays a more prominent role than it does in LMEs. These two institutions can promote the provision of firm-specific skills (Hall and Soskice, 2001b, pp. 24-25); this is also supported by the fact that many companies in these countries are financed by bank-based, and not equity, capital, 
which helps to foster commitment between employers and employees (Casper and Matraves, 2003; Hall and Soskice, 2001a). In LMEs, by contrast, companies do not have to liaise with worker representatives; they are also freer to hire and fire workers as they please: "top management normally has unilateral control over the firm" (Hall and Soskice, 2001b, p. 29). In addition, wage bargaining in the private sector in the USA and the UK takes place at the individual or firm level. These aspects will encourage workers to invest in general skills in order to ensure their continuing employment even if their current job comes to an end as the result of a change in the firm's strategy (Hall and Soskice, 2001b).

While, in some areas, such as collective bargaining, there are similarities between the new member states in CEE, there is a considerable amount of variation, in general, in employee relations in CEE. In terms of collective bargaining, for instance, much of it takes places at the company level in the new member states with the exceptions of Slovenia, where the national level is important, and Bulgaria and Slovakia, where the sector plays a key role (Knell and Srholec, 2007; Myant, 2007; Neumann, 2002; Nölke and Vliegenthart, 2009). This is not, however, to suggest that employee relations in most of the new EU member states resemble LMEs. For example, Buchen (2007) and Feldmann (2006) have argued that employee relations in Estonia largely conform to the LME model, while those in Slovenia resemble those associated with CMEs (see also, for Estonia, Kallaste et al., 2008). Myant (2007) has noted that trade unions are in decline in the Czech Republic. However, in the Czech Republic - and Slovakia - legislation enables works councils to be established in organizations, although in both countries their powers are much less than they are in Germany (Majtan, 2005; see also Stasek, 2005). In Poland, trade unions have been described as being relatively weak, and employee relations as consensual (Mykhnenko, 2007). In Hungary, workplace representation has been portrayed as informal and paternalistic (Richbell et al., 2010).

\section{Business regulations}

Although not explicitly dealt with in the VoC framework, the "ease of doing business" will be included here as a factor that can potentially influence the extent to which CEE countries are able to export high-tech goods. The inclusion of this factor is important for a number of reasons. First, given the emerging nature of the economies in CEE, overseas investors who are considering establishing subsidiaries in a foreign country may be deterred from doing so if that country is deemed to place too great a burden on the companies that operate there. This may be the case even if employment regulations are viewed favourably by those potential investors. Second, the failure to include this factor may mask the importance of the broader regulatory environment for business if it is correlated with employment regulations. In other words, if this factor is not included, a country's ability to be successful in exporting high-tech products may incorrectly be attributed to its level of employment regulations. Finally, a corollary of the convergence thesis is that those countries that most closely approximate the neo-liberal market model are the most likely to be successful in attracting foreign investors. In addition, the $\mathrm{VoC}$ paradigm, as noted above, makes the important point that radical innovation, which is a sine qua non, for success in high-tech markets is fostered more by LME-type institutional settings than it is by CME ones. The inclusion of a variable that measures the ease of doing business in a country is an appropriate way to capture these more general aspects of a country's business environment.

\section{Varieties of capitalism}

341 
ER

33,4

342

\section{Education levels}

Another factor that is likely to increase the level of exports of high-tech products is the availability of well-educated employees. In order to capture this possibility, this research includes the percentage of the labour force that has successfully completed a tertiary-level qualification. Tertiary education covers university undergraduate degrees. The inclusion of this variable is in line with related studies (see, for instance, Schneider et al., 2009). It will also help to shed light on the extent to which this factor is important to foreign investors and, hence, the extent to which states in CEE will have to promote not only the establishment of markets, but also social cohesion, by, for instance, increasing the numbers of those going to university. Furthermore, results for this factor may reveal a more positive economic outlook for the region. For instance, if foreign investors are attracted to a country because of its high levels of potential employees with a tertiary education, this could indicate that those firms wish to develop organizational capabilities in the country, and will not relocate further eastwards once cost advantages have dissipated.

\section{Data, and variable calibration}

In order to assess the extent to which FDI is likely to create pressures for economies in CEE to converge towards an LME-type model in their employee relations and corporate-governance regulations, all ten countries from CEE that joined the EU in either 2004 or 2007 have been included in the analysis. In order to ensure that the results are not biased by, for instance, large one-off investments by foreign firms, mean annual values for the five-year period (2003 until 2007, inclusive) have been used for most of the variables in this study. The year 2007 is the latest for which most measures are available. The data on employment and business regulations are only available for on year; however, these values do not suffer from large annual variations.

The outcome variable is export performance in high-tech industries, taken from the OECD's main science and technology indicators. Industries are classified according to their R\&D intensity (R\&D expenditure as a percentage of sales). High-technology exports cover products in a number of industries, including aerospace, computers and office machinery, pharmaceuticals, scientific and medical instruments, and communications equipment. By focusing on such sectors, this paper can shed light on the extent to which countries in CEE are being used to conduct comparatively low-skilled activities. If FDI mainly leads to the creation of unskilled and semi-skilled jobs, there will not be any links between such investments and success in high-tech markets.

The measure for export performance in high-tech industries is defined as high-tech exports as a percentage of all manufacturing exports. Data for this factor along with those for six of the causal conditions were collected from the World Bank's World Development Indicators dataset, which itself draws on a number of sources; data for the seventh on "participation" are from the European Trade Union Institute (ETUI). Table I, which contains the "raw data" for all of the variables used in this analysis, shows the high-tech export performance for the ten countries included in this analysis. The sources and definitions for the other data in Table I are set out in Table II. Poland and Romania have the lowest export shares, and the mean share for all ten countries is 6.6 per cent. 


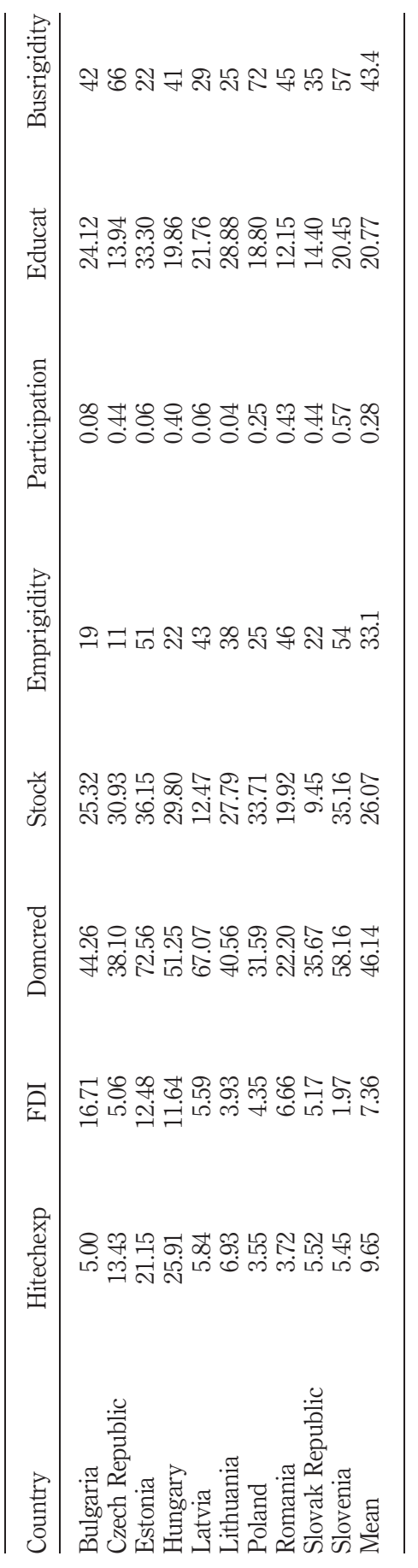

Varieties of capitalism

343

Table I. Data used in the analysis prior to transformation 


\section{ER \\ 33,4}

\section{4}

Table II.

Causal conditions:

definitions and sources

\begin{tabular}{lll}
\hline Variable & Definition & Source \\
\hline Hitechexp & $\begin{array}{l}\text { High-technology exports (\% of } \\
\text { manufactured exports) }\end{array}$ & $\begin{array}{l}\text { United Nations, Comtrade database. The } \\
\text { five-year mean (2003-2007, inclusive) has } \\
\text { been used }\end{array}$
\end{tabular}

Corporate governance

FDI Foreign direct investment, net inflows

( $\%$ of GDP)

International Monetary Fund,

International Financial Statistics and Balance of Payments databases, World

Bank, Global Development Finance, and

World Bank and OECD data. The five-year mean (2003-2007, inclusive) has been used

Domcred Domestic credit to private sector ( $\%$ of GDP)

International Monetary Fund,

International Financial Statistics and data files, and World Bank and OECD data.

The five-year mean (2003-2007, inclusive) has been used

Stock Market capitalization of indigenous listed Standard \& Poor's, Emerging Stock companies ( $\%$ of GDP)

Markets Factbook and supplemental S\&P data, and World Bank and OECD data.

The five-year mean (2003-2007, inclusive) has been used

Labour market

Emprigidity Rigidity of employment index $(0=$ less rigid to $100=$ more rigid)

World Bank, Doing Business project (www.doingbusiness.org/). Data are for 2008

Participation European Participation Index, measuring employees' plant-level, board-level, collective bargaining coverage, and trade union density $(1=$ highest level; $0=$ lowest level)

Educat Labour force with tertiary education (\% of total)

European Trade Union Institute (ETUI), http://www.worker-participation.eu/ About-WP/European-Participation-IndexEPI. Data are for 2006

International Labour Organization. The five-year mean (2003-2007, inclusive) has been used, except for Estonia and Romania (four-year mean, as data for 2004 are not available)

\section{Business regulation}

Busrigidity $\quad$ Ease of doing business index $(1=$ most business-friendly regulations)
World Bank, Doing Business project (www.doingbusiness.org/). Data are for 2008

In order to use the data as part of a fuzzy-set analysis, the figures had to be transformed. To establish the set membership values, three anchor points need to be determined: two extreme points defining full membership and full non-membership, and a crossover point at which the country is neither in nor out of the set (Ragin, 2000, pp. 158-9). These anchors are assigned set membership values of 1,0 , and 0.5 , respectively. A value of 1 was assigned to the country with the highest export share; 0 to the country with the lowest percentage. The cross-over point was calculated as the mena for all of the countries. Given these three anchor points, the set membership 
values for all cases were calculated by using the log odds method described by Ragin (2008). Using this measure, three countries are members of the "high-tech exports" set (Czech Republic, Estonia and Hungary). The same procedure that was used to calculate the set membership for high-tech exports was used for all of the causal conditions. This results in countries having varying membership for each institutional variable.

The first measure of corporate governance is FDI, which is assessed on the basis of net FDI inflows as a percentage of GDP. As noted above, large amounts of inward FDI will not necessarily result in strong export levels in advanced-technology goods. The second measure of corporate governance, domestic credit, captures the credit provided by, primarily, banks in one country to companies in the same country as a percentage of GDP. It, therefore, indicates the prevalence of domestic banks in funding economic activities. If companies in CEE are able to develop their competitive competencies without relying directly on foreign investors, they are likely to draw on domestic sources and funding; hence, there will be an association between this measure and success in exporting high-tech products. The third and final measure of corporate governance, broadly defined, is stock market capitalization, which is proxied by the market capitalization of indigenous companies as a percentage of GDP. Similar to the arguments put forward on domestic credit, if domestic firms can create capabilities that allow them to develop advanced technologies, there is likely to be a causal connection between high levels of stock-market capitalization and strong exports of high-tech goods.

In order to measure labour-market factors, two measures are included in the analysis. The "employment rigidity" index captures general employment legislation, while the other, the European Participation Index, measures workplace and board-level employee representation, collective bargaining coverage rates, and trade union density. The general regulatory environment is captured by the ease of doing business index expressed in the analysis as the rigidity of doing business in order to aid the interpretation of the results.

\section{Empirical analysis}

\subsection{Methodology}

Developed by Ragin (2000) and drawing on Boolean algebra, fuzzy-set qualitative comparative analysis (fsQCA) provides a means to assess the relationship between combinations of "causal conditions" and the outcome in question. In the analysis, all data are transformed into set memberships for the individual countries. A value of 1 indicates that a case is a full member of a particular set; a 0 denotes full "non-membership". A cross-over point, with a value of 0.5 , represents the anchor for a distinction between being in or out of a set. In short, fsQCA examines how the membership of cases in the set of causal conditions is linked to membership in the outcome set.

Like conventional statistical methods, fsQCA enables researchers to examine a higher number of cases than might be possible using many qualitative methods. However, unlike conventional statistical analytical techniques, such as multivariate analysis, fsQCA is based on the logic of set relations. This means that cases are considered differently in the two methods (Braumoeller and Goertz, 2000; Ragin, 2000, 2008). For instance, conventional statistical techniques would assess, in various ways, the correlation between two variables. However, the logic behind such a technique

\section{Varieties of capitalism}

345 
ER

33,4

346

would lead to certain values being considered as errors (Ragin, 2006). Yet, fsQCA, precisely because it is based on set-theoretic reasoning, consider the cases, at least in some instances, to be causally linked (Ragin, 2000, 2006).

An advantage of using fsQCA here is that it enables potential clusters of institutional configurations and, hence, countries to be identified. If any such clusters are found, this would reveal strong convergence tendencies among countries in the region. If, on the other hand, there are no clusters of either necessary or sufficient

causal conditions, such tendencies will be less. An additional advantage of the fsQCA approach is that it allows for the possibility that more than one combination of causal conditions may be found to be linked to the same outcome. In other words, there may be more than one way for countries to be successful exporters of high-tech goods. Hence, fsQCA captures the idea of equifinality, or functional equivalents (Fiss, 2007). This enables an assessment of the extent to which various institutional combinations can explain export performance in high-tech industries. This is important, as it allows this paper to assess whether or not countries in CEE are able to achieve the same objective - greater exports of high-tech goods - by different means.

Finally, unlike conventional statistical techniques which are based on examinations of sufficiency (Ragin, 2000, 2006), fsQCA can examine the links between various combinations of causal conditions and the outcome as both necessary and sufficient conditions. This is important here, as it is yet to be established whether certain institutional features are either necessary and/or sufficient for countries in CEE to achieve strong export records in high-tech products. The use of fsQCA means that causal conditions that are necessary and that are sufficient can be explored. These findings may, in turn, lead to clearer policy implications than would be the case from an analysis of the marginal effects obtained from regression analyses (Fiss, 2007, p. 1195; Schneider et al., 2009).

\section{Results}

8.1 Necessary conditions and functional equivalents

The analysis begins by examining whether any of the causal conditions can be considered "necessary" for the outcome. A necessary causal condition is one for which the instances of the outcome constitute a subset of the instances of the causal condition (Ragin, 2006, p. 297). In other words, a necessary cause, as Ragin (2000, p. 91) has noted, is one that "must be present for the outcome in question to occur". Its presence does not, however, "automatically" lead to the outcome. This means that, for each case, the values of the set membership for the outcome will be lower than the values for the set membership for the necessary cause. However, as the data do not, normally, conform to that specification, fsQCA draws on consistency measures, which are calculated using probabilities, to enable assessments of the degree to which observations meet the requirement of necessity. Following the consistency rule suggested by Ragin (2006, pp. 296-7), the analysis views near misses favourably, but sees those cases in which the scores for the causal membership greatly exceed those for the outcome membership negatively.

A consistency score of 1 denotes that the causal condition or combination of causal conditions meets the necessity rule across all cases. Consequently, values closer to 0 indicate either that many cases fail to conform to that rule and/or that there are a large proportion of cases that are a long way from meeting that rule. If a causal condition or a 
combination of them has a consistency score of 0.9 or above, this is, conventionally, deemed to be a "necessary" or "almost always necessary" condition.

Table III shows the results of the analysis of causal conditions for all six of the factors included here. Following convention, conditions that are written in lower case denote "non-membership" of that set; those in upper case represent membership. Individually, only one causal condition exceeds the threshold of 0.90. Somewhat surprisingly, perhaps, this is the measure of stock market capitalization. In other words, countries that have higher levels of stock market capitalization as a percentage of GDP create the necessary - but not sufficient - conditions for success in high-tech markets.

In order to test both the issues of governance and the extent to which member states in CEE might be able to create the resources that enable domestic companies to succeed in high-tech markets, the possibility that three separate functional equivalents exist is examined. This is done by assessing various "substitutable necessary conditions" in fsQCA (Ragin, 2006). This involves tests based on Boolean logic to establish whether to conditions joined by a logical "or" (+) are necessary conditions for the outcome. Once again, the threshold level of 0.9 is used. Of the three functional equivalents that are assessed (FDI + STOCK; FDI + DOMCRED; FDI + EDUCAT), only the first achieves a consistency level above the threshold. This suggests that strong inward FDI can be considered to be a functional equivalent to high levels of stock-market capitalization as a percentage of GDP, and vice versa. Importantly, therefore, countries in CEE may be able to avoid dependency status by encouraging the development of large domestic firms. The results also show, however, that efforts to raise education attainment levels are not a substitute for inward FDI.

\subsection{Sufficient conditions}

The analysis of sufficient conditions is based on the set-theoretic reasoning that a sufficient cause is one that, in a strict interpretation, leads to the outcome if, for all

\begin{tabular}{lcc}
\hline Conditions tested & Consistency & Coverage \\
\hline STOCK & 0.945 & 0.462 \\
FDI & 0.709 & 0.565 \\
DOMCRED & 0.695 & 0.447 \\
emprigidity & 0.641 & 0.372 \\
busrigidity & 0.618 & 0.324 \\
PARTICIPATION & 0.601 & 0.346 \\
Educat & 0.529 & 0.280 \\
EDUCAT & 0.527 & 0.346 \\
participation & 0.448 & 0.267 \\
BUSRIGIDITY & 0.430 & 0.285 \\
EMPRIGIDITY & 0.422 & 0.250 \\
domcred & 0.418 & 0.225 \\
fdi & 0.375 & 0.174 \\
stock & 0.137 & 0.100 \\
FDI + STOCK & 0.970 & 0.403 \\
FDI + DOMCRED & 0.758 & 0.390 \\
FDI + EDUCAT & 0.740 & 0.379
\end{tabular}

Notes: Outcome variable is hitechexp

\section{Varieties of capitalism}

347
Table III.

Analysis of necessary conditions 
ER

33,4

348 cases, the fuzzy-set membership value of the causal condition does not exceed the fuzzy membership value of the outcome (Ragin, 2006). Combinations of factors can be considered in the same way and are denoted by a logical "AND" (*). As individual cases or combinations of them are unlikely to satisfy the strict criterion for sufficiency across all cases, a consistency measure, as specified in Ragin (2006), is needed.

Those causal combinations that exceed a certain consistency score are categorized as sufficient. This leads to such cases being assigned a value of 1 in the truth table for the outcome (HITECH). Those causal combinations that have a consistency score below the cut-off point are not deemed to be sufficient, and they receive a score of 0 for the outcome. Using 0.80 as the cut-off point for sufficiency leads to the combinations of causal conditions and outcome shown in Table IV. Out of the 128 possible logical combinations of causal factors, 10 are observed. The fact that there are not fewer observed combinations suggests that there is little complementarity between the various institutions. In other words, having higher levels of, for instance, stock market capitalization does not mean that, say, employee-participation levels will be comparatively strong or weak. This evidence indicates that there has been little convergence around any particular institutional model or models among the CEE countries.

In order to examine the sufficiency of the causes for high-tech exports, a truth-table algorithm is applied. The "intermediate" solution is shown, which is recommended by Ragin (2008, pp. 160-175) for interpretation. Each line in Table V represents a combination of sufficient conditions that lead to the outcome. As can be seen, all sufficient causes consist of more than one condition. In short, there is no one condition that is, by itself, sufficient to account for strong high-tech export levels.

Two ways to achieve strong high-tech exports emerge from the sufficiency analysis. The scores for "raw coverage" and "unique coverage" that are shown in Table V help to assess the empirical importance of these two routes to success in advanced technology markets (Ragin, 2006). Raw coverage refers to the extent of the overlap between the causal combination set and the outcome set relative to the size of the outcome set (Ragin, 2006, p. 301). The measure for unique coverage controls for overlapping explanations by drawing on the raw coverage data. For any particular causal combinations, it is calculated by subtracting the raw-coverage score for all the other causal combinations (excluding the one of interest) from the raw-coverage score all causal combinations (including the one of interest). As there are only two causal combinations that explain success in high-tech markets, the unique coverage score for each combination is relatively high. This indicates that both are empirically important.

These two means to achieve success in high-tech export markets have much in common. For example, the results reveal that low levels of business regulations and high levels of stock market capitalization, domestic credit, and inward FDI are causal conditions that are shared between the two routes. The two countries with these characteristics, as Table IV shows, are Hungary and Estonia. There are, however, important differences between them. First, percentage of the populations of the two countries with a university degree varies considerable. In Hungary, it is below the mean for the ten new member states in CEE, while in Estonia it is well above average. There are important differences in the area of employee relations, too. While Hungary has relatively high levels of employee participation, Estonia does not. However, Estonia is deemed to have high general employment regulations, while Hungary does 


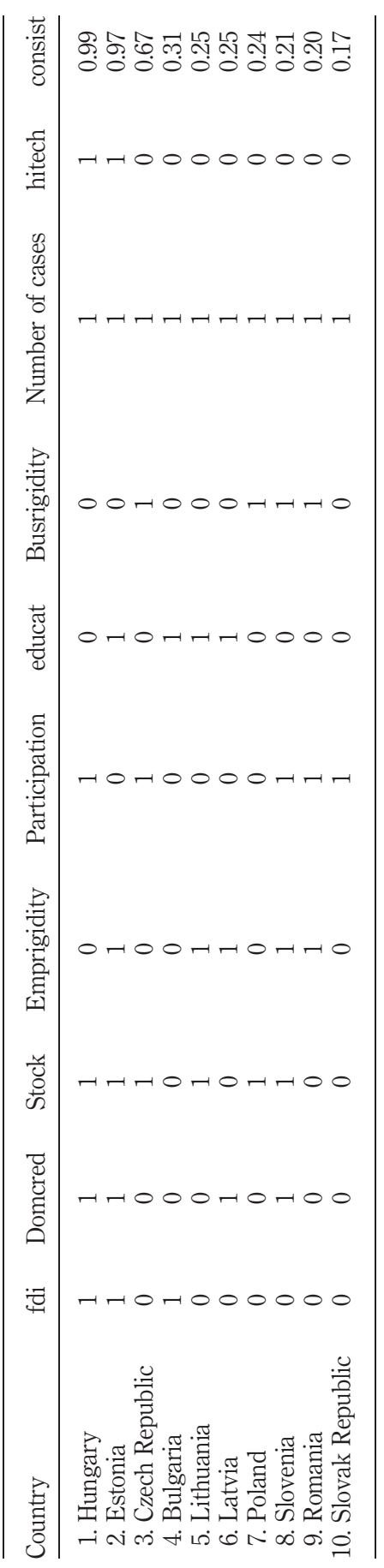

Varieties of capitalism

349

Table IV.

Truth table and assignment of countries to institutional configurations (logical remainders not listed) 
ER

33,4

\section{0}

Table V.

Sufficient combinations of conditions for strong export performance in high-tech not. Despite these differences, both countries are able to succeed in high-tech export markets. This has important implications, which are discussed below, for pressures for convergence.

\section{Discussion and implications for future research}

One of the important findings of this research is that there is a great deal of institutional diversity within the new EU member states in CEE. As the results show, there are no clusters of countries around specific varieties of capitalism - be it a CME, LME or dependent market economy model. This, in turn, suggests that the pressures for convergence are not as great as some have argued (Friedman, 2005; Prestowitz, 2005).

The finding that relatively high levels of FDI are part of causal combinations that are sufficient to lead to success in high-technology export markets has a number of important implications. First, in contrast to Nölke and Vliegenthart's (2009, p. 678) contention that multinational corporations "prefer to keep the most innovation-heavy activities at the headquarters" and in contrast to Bohle and Greskovits's (2007b) argument that "In the less developed part of the world [including CEE], neoliberalism is likelier to spell the fast decline of the most innovative industries, as these will be the first victims of the global competition with their advanced country rivals", companies in CEE have been successful in highly innovation sectors. Importantly, high levels of FDI form part of the explanation. Second, the ability to export high-technology products indicates that firms in the region have been able to attain sufficiently advanced organizational capabilities that enable them to absorb technologies that may have been developed. Finally, the ability of foreign-owned subsidiaries to do this suggests that they are likely to increase their autonomy within the MNC (Dörrenbächer, 2007). Hence, they will be able to exert a stronger influence over key decisions within the MNC. As a result, they will be able to take a more active role in significant developments within the MNC.

This focus on FDI should not, however, detract from the role played by domestic factors. For instance, greater levels of stock market capitalization and domestic credit are also consistently part of explanations that are sufficient to explain stronger high-tech exports. This indicates, once again, that domestic firms in the region are able to generate competitive competencies that give them an advantage on export markets. To be sure, foreign companies - in the form of institutional investors and foreign-owned banks in CEE - should not be excluded from this explanation. The point here is that firms in CEE that do not form part of MNCs are able to develop their

\begin{tabular}{lccc}
\hline Intermediate solution & Raw coverage & Unique coverage & Consist \\
\hline $\begin{array}{l}\text { busrigidity *educat *PARTICIPATION* } \\
\text { emprigidity *STOCK *DOMCRED*DI }\end{array}$ & & & \\
busrigidity *EDUCAT * participation* & 0.241 & 0.193 & 0.992 \\
EMPRIGIDITY*STOCK *DOMCRED*FDI & 0.380 & 0.332 & 0.974
\end{tabular}

Solution coverage: 0.573

Solution consistency: 0.982

Notes: +: Presence of either condition or of both conditions; *: Presence of both conditions; Calculation with fsQCA 2.0 software (www.fsqca.com) 
own capabilities that enable them to compete successfully: they are not dependent on capabilities to technologies that may have been generated elsewhere and then transferred to them. It is also important to note here that the only causal condition that was consistently necessary to explain success in high-tech export markets was domestic stock market capitalization. Although reverse causality may be a play here, the argument here is that domestic firms in the region have been able to develop capabilities to be competitive in high tech markets - even if stock markets capitalization values reflect that success rather than be a necessary condition for it.

Taken together, these necessary and sufficient causal conditions paint a more optimistic picture for the development of firms in CEE than that portrayed by others Bohle and Greskovits, 2007b; Dörrenbächer, 2007; Nölke and Vliegenthart, 2009). Foreign-owned subsidiaries do not act primarily as assembly facilities for standardized products, and they do not act as passive recipients of technology developed elsewhere. Where firms in CEE form part of MNCs they, the results indicate, have been able to develop their own competitive competencies. Similarly, those organizations that are not part of MNCs have been able to develop organizational capabilities that enable them to compete in advanced-technology markets.

A further common part of sufficiency-based explanations of success in high-tech markets is a relatively low level of business regulations. This is likely to be important to both foreign-owned and domestic firms in CEE, as practices that make doing business more difficult are likely to slow down the decision-making process within companies. This, in turn, will have a detrimental effect on the development of high-tech products, as reconfigurational capabilities are a sine qua non in such markets (Hall and Soskice, 2001a; Whitley, 2007).

In other areas, however, there are distinct differences between explanations of why some countries have greater export levels of high-tech goods than others. For instance, Hungary and Estonia, both of which have such records, have varying values for the percentage of the population with a university degree, the level of employee participation in companies, and employment regulations. Such variation indicates that there is more than one way for firms in CEE to be successful in advanced-technology markets.

The differences between the two empirically important causal combinations of factors that are sufficient to explain stronger levels of high-tech exports have important implications for the prospects of convergence in CEE. The results clearly indicate that low levels of employee participation are not universally sufficient to explain export success. These results are also corroborated by the findings that relate to necessary conditions, as such low levels were not consistently associated with success in high-tech markets. This acts as a warning against arguments to dismantle employment protection and forms of employee representation in companies (Harcourt and Wood, 2007). A reduction in these factors will not lead to greater success in high-tech sectors. Indeed, if changes were to be made this could have a detrimental effect on existing comparative advantages. This important finding together with the lack of any clusters emerging around particular institutional configurations suggests that - with the possible exception of increasing the ability of firms to do business there is likely to be much continued diversity throughout the region.

This research has been able to map that diversity as well as examine in a sophisticated way both the necessary and sufficient causal combinations for success in 
ER

33,4

352 high-tech exports markets. One area where this research could be extended is by undertaking a similar cross-country analysis at the micro or establishment level. This would help to uncover the complex interplay between, on the one hand, institutions and domestic and foreign strategic actors and, on the other, organizational capabilities and commercial specialization (Drahokoupil, 2009). In addition, such research will help to reveal intra-country diversity, which is attracting greater interest in the literature (Lane and Wood, 2009). Covering all ten new EU member states in CEE is likely to prove a daunting task; it is hoped, however, that this research has highlighted countries that could be examined fruitfully.

\section{References}

Allen, M.M.C. and Aldred, M.L. (2009), "Varieties of capitalism, varieties of innovation? A comparison of old and new EU member states", Journal of Contemporary European Research, Vol. 5 No. 4, pp. 581-96.

Allen, M.M.C., Funk, L. and Tüselmann, H.-J. (2006), "Can variation in public policies account for differences in comparative advantage?”, Journal of Public Policy, Vol. 26 No. 1, pp. 1-19.

Aoki, M. and Jackson, G. (2008), "Understanding an emergent diversity of corporate governance and organizational architecture: an essentiality-based analysis", Industrial and Corporate Change, Vol. 17 No. 1, pp. 1-27.

Barney, J. (1991), "Firm resources and sustained competitive advantage", Journal of Management, Vol. 17 No. 1, pp. 99-120.

Bohle, D. and Greskovits, B. (2006), "Capitalism without compromise: strong business and weak labor in Eastern Europe's new transnational industries", Studies in Comparative International Development, Vol. 41 No. 1, pp. 3-25.

Bohle, D. and Greskovits, B. (2007a), "Neoliberalism, embedded neoliberalism, and neocorporatism: paths towards transnational capitalism in Eastern Europe", West European Politics, Vol. 30 No. 3, pp. 443-66.

Bohle, D. and Greskovits, B. (2007b), “The state, internationalization, and capitalist diversity in Eastern Europe", Competition and Change, Vol. 11 No. 2, pp. 89-115.

Bohle, D., Radice, H. and Shields, S. (2007), "Introduction”, Competition and Change, Vol. 11 No. 2, pp. 81-7.

Boyer, R. (2004), "New growth regimes, but still institutional diversity", Socio-Economic Review, Vol. 2 No. 1, pp. 1-32.

Braumoeller, B.F. and Goertz, G. (2000), "The methodology of necessary conditions", American Journal of Political Science, Vol. 44 No. 4, pp. 844-58.

Buchen, C. (2007), "Estonia and Slovenia as antipodes", in Lane, D. and Myant, M. (Eds), Varieties of Capitalism in Post-Communist Countries, Palgrave Macmillan, London, pp. 65-89.

Casper, S. (2009), "Can new technology firms succeed in coordinated market economies? A response to Herrmann and Lange", Socio-Economic Review, Vol. 7 No. 2, pp. 209-15.

Casper, S. and Matraves, C. (2003), "Institutional frameworks and innovation in the German and UK pharmaceutical industry", Research Policy, Vol. 32 No. 10, pp. 1865-79.

Casper, S. and Whitley, R. (2004), "Managing competences in entrepreneurial technology firms: a comparative institutional analysis of Germany, Sweden, and the UK", Research Policy, Vol. 33 No. 1, pp. 89-106.

Cohen, W. and Levinthal, D. (1990), "Absorptive capacity: a new perspective on learning and innovation”, Administrative Science Quarterly, Vol. 35 No. 1, pp. 128-52. 
Crouch, C. (2005), Capitalist Diversity and Change: Recombinant Governance and Institutional Entrepreneurs, Oxford University Press, Oxford.

Crouch, C., Streeck, W., Boyer, R., Amable, B., Hall, P.A. and Jackson, G. (2005), "Dialogue on 'institutional complementarity and political economy", Socio-Economic Review, Vol. 3 No. 2, pp. 359-82.

Crowley, S. (2004), "Explaining labor weakness in postcommunist Europe: historical legacies and comparative perspective", East European Politics and Societies, Vol. 18 No. 3, pp. 394-429.

Czaban, L. and Henderson, J. (2003), "Commodity chains, foreign investment, and labour issues in Eastern Europe”, Global Networks, Vol. 3 No. 2, pp. 171-96.

Deeg, R. (2009), "The rise of internal capitalist diversity? Changing patterns of finance and corporate governance in Europe", Economy and Society, Vol. 38 No. 4, pp. 552-79.

Deeg, R. (2010), "Institutional change in financial systems", in Morgan, G., Campbell, J.L., Crouch, C., Pedersen, O.K. and Whitley, R. (Eds), The Oxford Handbook of Comparative Institutional Analysis, Oxford University Press, Oxford.

Djankov, S., Glaeser, E., La Porta, R., Lopez-de-Silnes, F. and Shleifer, A. (2003), "The new comparative economics", Journal of Comparative Economics, Vol. 31 No. 4, pp. 595-619.

Dörrenbächer, C. (2007), "Challenges for foreign-owned subsidiaries in FDI-led modernization strategies: the case of Hungary", Competition and Change, Vol. 11 No. 2, pp. 179-97.

Drahokoupil, J. (2009), "After transition: varieties of political-economic development in Eastern Europe and the former Soviet Union", Comparative European Politics, Vol. 7 No. 2, pp. 279-98.

Feldmann, H. (2004), "How flexible are labour markets in the EU accession countries Poland, Hungary, and the Czech Republic?", Comparative Economic Studies, Vol. 46 No. 2, pp. 272-310.

Feldmann, M. (2006), "Emerging varieties of capitalism in transition countries: industrial relations and wage bargaining in Estonia and Slovenia", Comparative Political Studies, Vol. 39 No. 7, pp. 829-54.

Fiss, P.C. (2007), "A set-theoretic approach to organizational configurations", Academy of Management Review, Vol. 32 No. 4, pp. 1190-8.

Friedman, T.L. (2005), The World is Flat, Farrar, Straus and Giroux, New York, NY.

Gospel, H. and Pendleton, A. (2004), Corporate Governance and Labour Management: An International Comparison, Oxford University Press, Oxford.

Hall, P.A. and Soskice, D. (2001a), The Varieties of Capitalism: The Institutional Foundations of Comparative Advantage, Oxford University Press, Oxford.

Hall, P.A. and Soskice, D. (2001b), "Introduction", in Hall, P.A. and Soskice, D. (Eds), Varieties of Capitalism: The Institutional Foundations of Comparative Advantage, Oxford University Press, Oxford, pp. 1-68.

Hansmann, H. and Kraakman, R. (2000), "The end of history for corporate law”, Georgetown Law Journal, Vol. 89, pp. 439-68.

Harcourt, M. and Wood, G. (2007), "The importance of employment protection for skill development in coordinated market economies", European Journal of Industrial Relations, Vol. 13 No. 2, pp. 141-59.

Henderson, J. (1998), "On appropriate models for transformation in Eastern Europe", in Henderson, J. (Ed.), Industrial Transformation in Eastern Europe in the Light of the East Asian Experience, Macmillan, London, pp. 1-23.

Höpner, M. (2005), "What connects industrial relations and corporate governance? Explaining institutional complementarity", Socio-Economic Review, Vol. 3 No. 2, pp. 331-58. 
ER

33,4

354

Jackson, G. (2005), "Employee representation in the board compared: a fuzzy sets analysis of corporate governance, unionism and political institutions", Industrielle Beziehungen, Vol. 12 No. 3, pp. 252-79.

Kallaste, E., Jaakson, K. and Eamets, R. (2008), “Two representatives but no representation: cases from Estonia”, Employee Relations, Vol. 30 No. 1, pp. 86-97.

King, L.P. (2007), "Central European capitalism in comparative perspective”, in Hancké, B., Rhodes, M. and Thatcher, M. (Eds), Beyond Varieties of Capitalism: Conflict, Contradictions, and Complementarities in the European Economy, Oxford University Press, Oxford, pp. 307-27.

King, L. and Sznajder, A. (2006), "The state-led transition to liberal capitalism: neoliberal, organizational, world systems, and social structural explanations of Poland's economic success", American Journal of Sociology, Vol. 112 No. 3, pp. 751-801.

Knell, M. and Srholec, M. (2007), "Diverging pathways in Central and Eastern Europe”, in Lane, D. and Myant, M. (Eds), Varieties of Capitalism in Post-Communist Countries, Palgrave Macmillan, London, pp. 40-62.

Lane, C. and Wood, G. (2009), "Capitalist diversity and diversity within capitalism”, Economy and Society, Vol. 38 No. 4, pp. 531-51.

Lane, D. (2005), "Emerging varieties of capitalism in former state socialist societies", Competition and Change, Vol. 9 No. 2, pp. 27-47.

Lane, D. (2007), “Post-state socialism: a diversity of capitalisms?”, in Lane, D. and Myant, M. (Eds), Varieties of Capitalism in Post-Communist Countries, Palgrave Macmillan, London, pp. 13-39.

Lane, D. and Myant, M. (Eds) (2007), Varieties of Capitalism in Post-Communist Countries, Palgrave Macmillan, London.

McCahery, J.A., Renneboog, L., Ritter, P. and Haller, S. (2004), "The economics of the proposed European Takeover directive", in Ferrarini, G., Hopt, K.J., Winter, J. and Wymeersch, E. (Eds), Reforming Company and Takeover Law in Europe, Oxford University Press, Oxford, pp. 575-646.

Majtan, B. (2005), “The labour code in the Republic of Slovakia”, Employee Relations, Vol. 27 No. 6, pp. 603-12.

Morgan, G. (2005), "Institutional complementarities, path dependency, and the dynamics of firms", in Morgan, G., Whitley, R. and Moen, E. (Eds), Changing Capitalisms? Internationalization, Institutional Change, and Systems of Economic Organization, Oxford University Press, Oxford.

Morgan, G. (2009), "Globalization, multinationals and international diversity", Economy and Society, Vol. 38 No. 4, pp. 629-54.

Myant, M. (2007), “The Czech Republic: from 'Czech' capitalism to 'European' capitalism”, in Lane, D. and Myant, M. (Eds), Varieties of Capitalism in Post-Communist Countries, Palgrave Macmillan, London, pp. 105-23.

Mykhnenko, V. (2007), "Strengths and weaknesses of 'weak' coordination: economic institutions, revealed comparative advantages, and socioeconomic performance of mixed market economies in Poland and Ukraine”, in Hancké, B., Rhodes, M. and Thatcher, M. (Eds), Beyond Varieties of Capitalism: Conflict, Contradictions, and Complementarities in the European Economy, Oxford University Press, Oxford, pp. 351-78.

Neumann, L. (2002), "Does decentralized collective bargaining have an impact on the labour market in Hungary?", European Journal of Industrial Relations, Vol. 8 No. 1, pp. 11-31. 
Nölke, A. and Vliegenthart, A. (2009), "Enlarging the varieties of capitalism: the emergence of dependent market economies in East Central Europe", World Politics, Vol. 61 No. 4, pp. $670-702$.

OECD (2005), Handbook on Economic Globalisation Indicators, OECD, Paris.

Pajunen, K. (2008), "Institutions and inflows of foreign direct investment: a fuzzy-set analysis", Journal of International Business Studies, Vol. 39 No. 4, pp. 652-69.

Polanyi, M. (1966), The Tacit Dimension, Doubleday, Garden City, NY.

Prestowitz, C. (2005), Three Billion New Capitalists: The Great Shift of Wealth and Power to the East, Basic Books, New York, NY.

Ragin, C.C. (2000), Fuzzy-Set Social Science, Chicago University Press, Chicago, IL.

Ragin, C.C. (2006), "Set relations in social research: evaluating their consistency and coverage", Political Analysis, Vol. 14 No. 3, pp. 291-310.

Ragin, C.C. (2008), Redesigning Social Inquiry: Fuzzy Sets and Beyond, University of Chicago Press, Chicago, IL.

Richbell, S., Szerb, L. and Vitai, Z. (2010), "HRM in the Hungarian SME sector", Employee Relations, Vol. 32 No. 3, pp. 262-80.

Schneider, M.R., Schulze-Bentrop, C. and Paunescu, M. (2009), "Mapping the institutional capital of high-tech firms: a fuzzy-set analysis of capitalist variety and export performance", Journal of International Business Studies, Vol. 41 No. 2, pp. 246-66.

Shields, S. (2007), "Too much shock, not enough therapy: transnational capital and the social implications of Poland's ongoing transition to a market", Competition and Change, Vol. 11 No. 2, pp. 155-78.

Stasek, F. (2005), "Employee relations in the Czech Republic - past, present and future", Employee Relations, Vol. 27 No. 6, pp. 581-91.

Vaughan-Whitehead, D. (2003), EU Enlargement versus Social Europe? The Uncertain Future of the European Social Model, Edward Elgar, Cheltenham.

Walgenbach, P. and Meyer, R.E. (2008), "Institutional entrepreneurship and the structuring of organizations and markets", in Ebner, A. and Beck, N. (Eds), The Institutions of the Market: Organizations, Social Systems, and Governance, Oxford University Press, Oxford.

Whitley, R. (1999), Divergent Capitalisms: The Social Structuring and Change of Business Systems, Oxford University Press, Oxford.

Whitley, R. (2007), Business Systems and Organizational Capabilities The Institutional Structuring of Competitive Competences, Oxford University Press, Oxford.

\section{Further reading}

Thatcher, M. (2007), Internationalisation and Economic Institutions Comparing the European Experience, Oxford University Press, Oxford.

\section{Corresponding author}

Matthew M. C. Allen can be contacted at: Matthew.allen@mbs.ac.uk

\footnotetext{
To purchase reprints of this article please e-mail: reprints@emeraldinsight.com
} Or visit our web site for further details: www.emeraldinsight.com/reprints 